\title{
潜在記憶における構造記述システムの符号化と両眼立体 視の関係
}

\author{
東海女子大学 西野由利恵 ${ }^{1,2}$
}

Relationship between encoding of the structural description system in implicit memory and binocular stereopsis Yurie Nishino (Tokai Women's University, Nakakirino, Kakamigahara 504-8511)

I investigated the relationship between encoding of the structural description system and binocular stereopsis. The structural description system is a component of the implicit memory system, and retains representations of possible figures. According to the previous studies, the priming effect based on it was produced only when the direction of the stimulus, which was the line drawing of the 3-dimensional object, was judged in the study phase. Because the judgment requires 3-dimensional processing, I proposed a hypothesis that the priming effect is also produced by binocular stereopsis in the study phase, and examined it by two priming experiments, in which different five undergraduates participated respectively. In the study phase, the primer was presented in binocular disparity (Experiment 1) or monocularly (Experiment 2), and the participants judged which lines were more, horizontal or vertical. In the test phase, the participants judged that the monocular stimulus was symmetrical or asymmetrical. The priming effect was produced only in Experiment 1, and was not in Experiment 2. The results supported the hypothesis, and suggest that encoding needs 3-dimensional processing in the structural description system.

Key words: implicit memory, structural description system, priming effect, stereopsis.

本論文の目的は，潜在記憶における構造記述システ ムの特性を検討する研究の一環として, その符号化に 両眼立体視が及ぼす影響を検討した実験の結果を報告 することである。構造記述システムは, 実空間に存在 できる可能図形の表象のみを保持する潜在記憶システ ムで (Schacter, Cooper, \& Delaney, 1990; Schacter, Cooper, Delaney, Peterson, \& Tharan, 1991)， 7 か月の 長期間にわたる保持が報告されている（西野，2000）。 検索時の刺激の大きさが符号化時と異なっていても, その影響を受けず，左右が反転していても，影響を受 けない (Cooper, Schacter, Ballesteros, \& Moore, 1992).

構造記述システムに基づくプライミング効果を示し た実験では，学習時に刺激の方向を判断する方向判断 課題を用いていた (Cooper et al., 1992; 西野, 2000: Schacter et al., 1990; Schacter et al., 1991; Tulving \&

\footnotetext{
本研究のアイディアは, 中京大学・鈴木雅洋さんとのディ スカッションによって得られたものです。なお, 彼には, 本研 究を進めるにあたり様々な側面においてご支援頂きました。ま た, ご指導頂きました中京大学・森孝行教授, 実験の実施にご 協力頂きました中京大学・高瀬玲子さん, 服部理さん, 近藤行 人さんに心から感謝致します。

2 本研究は, 著者が現所属抒よび中京大学文学研究科在籍中 に行われ, 実験実施は東海女子大学および中京大学において行 われた。
}

Schacter, 1990)。刺激の縱線と横線どちらが多いか判 断する線本数判断課題を用いると，プライミング効果 が生じない（Schacter et al., 1990)。これらは, 構造記 述システムの符号化に必要な処理が方向判断課題に特 有であることを示している，本論文において報告する 実験では，この処理に注目し，それを検討することを 目的とした。

刺激の方向を判断するには，基準となる“何か” （例えば，正面）が定められなければならない。その 基準は，刺激が立体的であれば，三次元的に定められ る必要がある.刺激に立体的線画図形を用いた方向判 断課題は，三次元的な処理を必要とすることが特徵の 一つである。

刺激の縦線と横線どちらが多いかの判断は，三次元 的な処理を経なくても，その前の二次元的レベルの処 理（例えば，線の検出）に基づいて行うことが十分に 可能である. 線本数判断課題では, 刺激に立体的線画 図形を用いても，三次元的な処理が必要とされない. これは，方向判断課題と大きく異なる点である.

実験 I では，方向判断課題における刺激の三次元的 な処理に注目し，刺激が三次元的に処理されさえすれ ば, 学習に方向判断課題を用いなくても, 構造記述シ ステムに基づくプライミング効果が生じるか否かを検 討した，具体的には，プライマを両眼立体視による奥 行き知覚の中で，すなわちステレオグラムによって提 
示し，学習に線本数判断課題を用いて，対称性判断の プライミング効果を調べた。 方法, 結果と考察は, 次 の通りである。

\section{実 験 I}

\section{方 法}

デザイン 実験 I は, 線本数判断課題と対称性判断 課題によって構成された。線本数判断課題は, 対称性 判断課題のプライマの提示を目的としたもので，対称 性判断課題の前日に行われた。線本数判断課題では, 刺激がステレオグラムによって提示された。対称性判 断課題では，刺激（ステレオグラムのハーフイメー ジ）が単眼に提示され ${ }^{3}$, 学習条件と未学習条件が被 験者内要因として設けられた。学習条件では，プライ マが線本数判断課題において提示された. 未学習条件 では，プライマが提示されなかった。

刺激材料 対称図形 20 個，非対称図形 20 個が刺激 として用いられた（Figure 1)。対称図形は，中央を 通過する面によって二分した図形が鏡映の関係である か (Figure 1A), 全く同じになった（Figure 1B). 非対称図形は，どの面によって二分されても，二分さ れた図形が全く異なり，鏡映の関係にもならなかった (Figure 1C). 線本数判断課題に打いて用いられたス テレオグラムでは, 周囲の枠（正方形・縦 $15.6^{\circ} \times$ 横 $\left.15.6^{\circ}\right)$ と刺激の最前部が最も手前に位置するように 両眼網膜非対応を与えた。両眼網膜非対応の量（最大 で $\left.21^{\prime}\right)$ は，両眼立体視が成立した時に不自然に見え ないよう，適切に配慮した。

装置 刺激の提示には, 岩通アイセル製 AVタキ ストスコープ (IS-701D) とアップルコンピュータ製 パーソナルコンピュータ (Power Macintosh 8500/ 120), 反射式ステレオスコープが用いられた。AVタ キストスコープとパーソナルコンピュータは, 被験者 の反応の記録にも用いられた。

被験者 正常な視力（矯正視力を含む）を有する中

\footnotetext{
3 対称性判断のプライミング効果は, いわゆる直接プライミ ング効果であり, 学習とテストの間で刺激が同一であることが 望まれる。しかし, 実験 I の場合, 学習である線本数判断課題 では両眼網膜非対応を与えた刺激を，テストである対称性判断 課題では両眼網膜非対応がない刺激を提示するので, 全く同一 にはなり得ない. ステレオグラムの融合像の平面図を対称性判 断課題の刺激とすると, 左眼・右眼の刺激が線本数判断課題と 異なる.ステレオグラムのハーフイメージを対称性判断課題の 刺激とすれば, 左眼・右眼の刺激どちらか一方が線本数判断課 題と同一となるが, これを両眼提示すると，もう一方が線本数 判断課題と異なる.そこで, 単眼刺激として提示し, この異な る刺激を提示しないようにした（なお，この異なる刺激を提示 すると，プライミング効果が生じなかった。この実験は，付録 として報告する)。できる限り刺激を同一にするための措置とし ては,これが最善であろう.
}

京大学の学部学生 5 人が参加した.

手続き 線本数判断課題において被験者に与えられ た課題は，提示された刺激の縦線と横線どちらが多い かを口頭によって報告することであった，判断は，直 感的な印象に基づくものとし，あまり考え込んで判断 しないよう教示した。毎試行，ノニアスによって凝視 の位置を確認してから刺激を提示し，両眼立体視の成 立を確認してから線本数判断課題を行った. 刺激は, 被験者が報告するまで提示され4, 報告した後, 直ち に消された. 3 人の被験者は，20 個の対称図形から無 作為に抽出した対称図形 10 個, 20 個の非対称図形か ら無作為に抽出した非対称図形 10 個に対して線本数 判断課題を行った. 残り 2 人の被験者は, 残りの対称 図形 10 個, 非対称図形 10 個に対して線本数判断課題 を行った。これらの対称図形, 非対称図形は, 1 試行 において 1 個ずつ提示された。このような線本数判断 課題は，6試行の練習の後に開始された。練習では, 実験で用いられる刺激と別の刺激（対称図形 3 個, 非 対称図形 3 個）が用いられた。

一方，対称性判断課題において被験者に与えられた 課題は, 提示された刺激が対称図形か非対称図形かを できる限り速く正確に判断し，対称なら右のボタン, 非対称なら左のボタンを押すことであった．右眼に注 視点が 1 秒間提示されてから右眼に刺激が 100 ミリ秒 間提示され, 最後に右眼にマスク刺激（刺激全体を覆 う大きな×印）が 1 秒間提示された，各被験者は，学 習条件の（線本数判断課題において提示された）対称 図形 10 個と非対称図形 10 個, 未学習条件の（線本数 判断課題において提示されなかった）対称図形 10 個

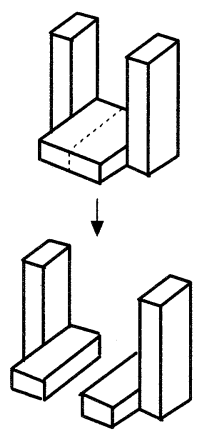

(A)

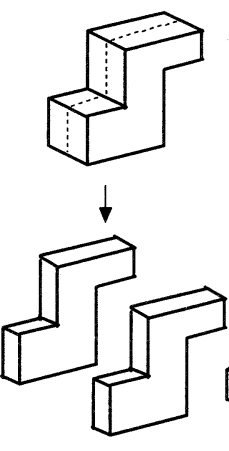

(B)

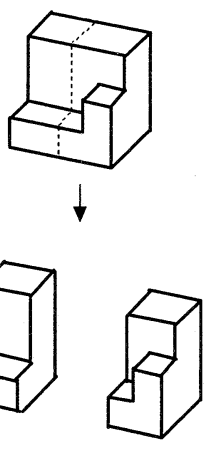

(C)
Figure 1. Illustration showing symmetrical and asymmetrical figures used in this study. Symmetrical figures consisted of two "mirror image" pieces (A) or two identical pieces (B). Asymmetrical figure consisted of two unpaired pieces (C).

4 実験 Iでは, 厳密な反応時間測定を行わなかったが, 参考と して, 実験者による手動計測を行った。その結果，平均値は， 約 5 秒であった。 
と非対称図形 10 個に対して対称性判断課題を行った. これらの対称図形，非対称図形は，1試行において1 個ずつ提示された。このような対称性判断課題は, 約 5 分間の休熄を挟んで 2 回に分けて行われ，2回とも 6 試行の練習の後に開始された。練習では, 実験にお いて用いられる刺激と別の刺激（対称図形 6 個，非対 称図形 6 個）が用いられた。

\section{結果と考察}

対称性判断課題の結果を Table 1 に示す. Table 1 では，学習条件の “対称図形と判断した試行数”の平 均值と “非対称図形と判断した試行数” の平均值, 未 学習条件の “対称図形と判断した試行数” の平均値と “非対称図形と判断した試行数” の平均值が対称図形, 非対称図形ごとに示されている。つまり，“対称図形 に対して対称図形”と判断した試行”と“非対称図形 に対して“非対称図形”と判断した試行” は，正答した 試行, “対称図形に対して ‘非対称図形”と判断した試 行”と “非対称図形に対して“対称図形”と判断した試 行” は，誤答した試行となる。対称図形の正答した試 行数の平均值は, 学習条件が末学習条件より大きかっ た. 対称図形の誤答した試行数の平均值は, 学習条件 が未学習条件より小さかった。非対称図形の正答した 試行数の平均值と誤答した試行数の平均値は, 学習条 件と末学習条件で同じであった。

ところで，対称性判断課題は，反応時間が 1 秒を超 えることから（西野，1996），その遂行では極めて高 次の表象の操作が行わ机ていると考えられている（西 野，2000). したがって，その結果を単純な反応モデ ルに基づいた理論（例えば，信号検出理論）によって 分析することは，適切ではないであろう。課題遂行過 程に関する議論に基づいて分析することが必要とな る.

このような問題に関して，西野（2000）は，誤答が 産出される過程に注目し，正答の中に“見かけ上の正 答（課題遂行上のエラー，および無作為反応による正 答)”が含まれていることを指摘している．また，正 答から見かけ上の正答を除外した “真の正答” 基づ いて分析を行うべきであると主張している。この議論 によれば, 見かけ上の正答数は, 誤答数から推定で き, したがって, 真の正答数は, 正答数から誤答数を 引くことによって求められる.

Table 1 の結果を西野 (2000) の議論に従って分析 した結果をTable 2 に示す. Table 2 には, 西野 （2000）の議論に従って求めた真の正答数が示されて いる. 学習条件の真の正答数は, 未学習条件より有意 に大きかった $(t(8)=2.12, p<.05)$.これらの結果 は, 学習条件において対称性判断のプライミング効果 が生じたことを示している。

従来の研究では, 学習に線本数判断課題を用いる
Table 1

Results of symmetry judgement task in Experiment 1

\begin{tabular}{llll}
\hline Stimulus type & Condition & \multicolumn{2}{c}{ Response } \\
& & "Symmetrical" "Asymmetrical" \\
\hline \multirow{2}{*}{ Symmetrical } & Studied & $9.0^{\mathrm{a})}(1.10)^{\mathrm{b})}$ & $1.0(1.10)$ \\
& Non-studied & $7.0(1.55)$ & $3.0(1.55)$ \\
& & & \\
Asymmetrical & Studied & $0.8(1.60)$ & $9.2(1.60)$ \\
& Non-studied & $0.8(0.40)$ & $9.2(0.40)$
\end{tabular}

a) Mean response of five paricipants. Minimum is 0 , and maximum is 10 .

b) Standard deviation.

Table 2

True hits in the results of symmetry judgement task in Experiment 1

\begin{tabular}{cl}
\hline Condition & \multicolumn{1}{c}{ True hits } \\
\hline Studied & $16.4^{\mathrm{a})}(2.94)^{\mathrm{b})}$ \\
Non-studied & $12.4(2.94)$
\end{tabular}

a) Mean number of true hits for five participants.

Minimum is 0 , and maximum is 20 .

b) Standard deviation.

と, 構造記述システムに基づくプライミング効果が生 じなかった (Schacter et al., 1990). しかし，プライマ をステレオグラムによって提示すれば，学習に線本数 判断課題を用いても，プライミング効果が生じる. 両 眼立体視という三次元的な処理が構造記述システムの 符号化を引き起こしたと言える。

\section{実 験 II}

学習に線本数判断課題を用い, 構造記述システムに 基づくプライミング効果が生じなかった従来の研究で は, テストに可能・不可能判断課題を用いていた (Schacter et al., 1990)。一方, 実験 Iでは, 対称性判 断課題を用いていた。両者の結果の違いは, テストの 違いとして説明できる可能性が否定できない.

実験 II では，テストに対称性判断課題を用いると， 学習に線本数判断課題を用いても, 構造記述システム に基づくプライミング効果が生じるか否かを検討し た。具体的には, プライマをステレオによって提示せ ず, 単眼のみに提示し, 学習に線本数判断課題を用い て, 対称性判断のプライミング効果を調べた. 方法, 結果と考察は，次の通りである。

\section{方 法}

刺激材料, 装置, 対称性判断課題の手続きは, 実験 I と同じであった。デザインと被験者, 線本数判断課 
題の手続きは，以下の通りであった。

デザイン 線本数判断課題の刺激が異なったこと以 外は, 実験 I と同じであった. 実験 II の線本数判断 課題では, 実験 I の線本数判断課題におけるステレオ グラムのハーフイメージが単眼に提示された 5 .

被験者 実験 I に参加していない中京大学の学部学 生 5 人が参加した. 全員が正常な視力（矯正視力を含 む)を有していた。

線本数判断課題の手続き 注視点と刺激が右眼に提 示された点が実験 I と異なった. 毎試行, 兩眼立体視 が成立していないことを確認してから線本数判断課題 を行っだ.

\section{結果と考察}

対称性判断課題の結果を Table 3 に示す. Table 3 では, 学習条件の “対称図形と判断した試行数”の平 均值と “非対称図形と判断した試行数” の平均值, 未 学習条件の“対称図形と判断した試行数” の平均值と “非対称図形と判断した試行数”の平均值が対称図形, 非対称図形ごとに示されている。対称図形の正答した 試行数の平均值は, 学習条件が未学習条件より大きか った. 対称図形の誤答した試行数の平均值は, 学習条 件が未学習条件より小さかった. 非対称図形の正答し た試行数の平均值と誤答した試行数の平均值は, 学習 条件と末学習条件で同じであった。

Table 3 の結果を西野（2000）の議論に従って分析 した結果をTable 4 に示す. Table 4 には, 西野 （2000）の議論に従って求めた真の正答数が示されて いる. 学習条件の真の正答数は, 未学習条件と同じ程 度であった. また, $t$ 検定の結果は, 学習条件と未学 習条件の真の正答数に有意差がないことを示した $(t(8)=0.16, n s)$. これらの結果は, 対称性判断のプ ライミング効果が生じなかったことを示している.

学習に線本数判断課題を用いた場合, テストに対称 性判断課題を用いても，プライマをステレオによって 提示しなければ, 構造記述システムにおけるプライミ ング効果が生じなかった. 従来の研究と (Schacter et al., 1990）実験 I の結果の違いをテストの違いによっ て説明できる可能性は, 支持されなかった。実験 I に おいて構造記述システムの符号化を引き起こした要因 は,やはり，両眼立体視であろう。

\footnotetext{
5 実験 II のデザインにおいて最も優先されるべきことは, 実 験 I との間で結果の比較を容易にするため, 対称性判断課題の 刺激を単眼に提示することである. したがって, 線本数判断課 題の刺激は, これと同一であることが最善である.

6 実験 II でも, 厳密な反応時間測定を行わなかったが, 参考 として, 実験者による手動計測を行った. その結果, 平均值は, 約 5 秒であった。
}

Table 3

Results of symmetry judgement task in Experiment 2

\begin{tabular}{llll}
\hline Stimulus type & Condition & \multicolumn{2}{c}{ Response } \\
& & "Symmetrical" "Asymmetrical" \\
\hline \multirow{2}{*}{ Symmetrical } & Studied & $7.8^{\mathrm{a})}(1.72)^{\mathrm{b})}$ & $2.2(1.72)$ \\
& Non-studied & $7.6(1.02)$ & $2.4(1.02)$ \\
& & & \\
Asymmetrical & Studied & $1.0(0.89)$ & $9.0(0.89)$ \\
& Non-studied & $1.0(1.10)$ & $9.0(1.10)$
\end{tabular}

a) Mean response of five paricipants. Minimum is 0 , and maximum is 10 .

b) Standard deviation.

Table 4

True hits in the results of symmetry judgement task in Experiment 2

\begin{tabular}{cl}
\hline Condition & \multicolumn{1}{c}{ True hits } \\
\hline Studied & $13.6^{\mathrm{a})}(4.08)^{\mathrm{b}}$ \\
Non-studied & $13.2(3.71)$
\end{tabular}

a) Mean number of true hits for five participants. Minimum is 0 , and maximum is 20 .

b) Standard deviation.

\section{総合考察}

構造記述システムに基づくプライミング効果は，こ れまで，学習に方向判断課題を用いた実験に抢いての み報告されてきた（Cooper et al., 1992; 西野, 2000; Schacter et al., 1990; Schacter et al., 1991; Tulving \& Schacter, 1990)。これに対し, 本論文の実験では, プ ライマをステレオによって提示すれば, 学習に方向判 断課題を用いなくても, プライミング効果が生じるこ と, すなわち両眼立体視が構造記述システムの符号化 を引き起こすことが示された.この結果は, 構造記述 システムの符号化が三次元的な処理を必要とすること を示す根拠として注目に值しよう。今後の検討が待た れる。

ところで, Marr（1982 乾・安藤訳，1987）によ れば，網膜に投映された二次元の網膜像から三次元の 構造を復元する過程は, 次の 3 段階に分けられる.

(a) 原始スケッチ：網膜に投映された網膜像から明る さの変化を検出し, 局所的な幾何学的構造の分析や照 明効果の検出などを行う。（b） $2^{1 / 2}$ 次元スケッチ：原 始スケッチから可視表面の幾何学的構造を観察者中心 座標系において記述する.（c）三次元モデル表現： $2^{1 / 2}$ 次元スケッチから物体の物理的表面の幾何学的構 造を物体中心座標系において記述する。

このような三次元の構造が復元される過程を考慮に 
入れると, 構造記述システムの符号化が必要とする三 次元的な処理は, どのように議論できるであろうか. ここで若干の議論を付け加えたい. 両眼立体視が構造 記述システムの符号化を引き起こすことから，符号化 に必要とされる三次元的な処理は, 可視表面の幾何学 的構造を観察者中心座標系において記述するといった レベルであると考えられる。仮に，それより高次の処 理（例えば，物体の物理的表面の幾何学的構造を物体 中心座標系において記述し，正面を定める）が必要で あるとすれば, 符号化は, 両眼立体視のみによって引 き起こされず, 方向判断課題など, より高次の処理を 必要とする課題によって引き起こされるはずである. 一方，それより低次の処理（例えば，可視表面の幾何 学的構造を観察者中心座標系において記述するための 手掛かりを検出する) で十分である可能性は，否定で きないが，仮に，そうであるとすれば，不可能図形が 符号化されてしまう。可能図形の表象のみが保持され ることから (Schacter et al., 1990; Schacter et al., 1991)，その可能性も，また考元難い. この議論は, 裏を返せば，不可能図形を符号化しないメカニズムの 説明として注目できる.すなわち, 可視表面の幾何学 的構造を観察者中心座標系に扔いて記述することが符 号化に必要とされるので，それが不可能である不可能 図形は，符号化されない，解が一義的に定まらない不 良設定問題である三次元の構造の復元では, 解を一義 的に定めるために実空間の様々な制約を利用しなけれ ばならないので（行場，1995），実空間の制約に合致 しない要素をもつ不可能図形の三次元の構造は, 復元 されないと考えられる。

本論文の成果は, 構造記述システムの特性を検討し て行く上で，両眼立体視による符号化という実験の手 法，あるいは視覚情報処理を含んだ新たな問題への拡 張的発展など，重要な発想を提供するであろう。これ らを踏まえ, 構造記述システムの特性を検討していく ことが今後の課題となる.

\section{引用文献}

Cooper, L. A., Schacter, D. L., Ballesteros, S., \& Moore, C. 1992 Priming and recognition of transformed three-dimensional objects: Effects of size and reflection. Journal of Experimental Psychology: Learning, Memory, and Cognition, 18, 43-57. 行場次朗 1995 視覚パターンの認知 乾 敏郎(編) 認知心理学 1 知覚と運動 東京大学出版会 $\mathrm{Pp}$. 117-141.

(Gyoba, J.)

マーD. 乾 敏郎・安藤広志(訳) 1987 ビジョン ——視覚の計算理論と脳内表現——産業図書

(Marr, D. 1982 Vision: A computational investigation into the human representation and processing of visual information. San Francisco: W. H. Freeman.)

西野由利恵 1996 図形刺激を用いたプライミング効 果による潜在記憶の検討 中京大学大学院文学研究 科修士論文 (未公刊)

(Nishino, Y.)

西野由利恵 2000 構造記述システムにおける図形表 象の長期保持 基礎心理学研究，19，1-7.

(Nishino, Y. 2000 Long-term retention for pictorial representation in the structural description system. Japanese Journal of Psychonomic Science, 19, 1-7.)

Schacter, D. L., Cooper, L. A., \& Delaney, S. M. 1990 Implicit memory for unfamiliar objects depends on access to structural descriptions. Journal of Experimental Psychology: General, 119, 5-24.

Schacter, D. L., Cooper, L. A., Delaney, S. M., Peterson, M. A., \& Tharan, M. 1991 Implicit memory for possible and impossible objects: Constraints on the construction of structural descriptions. Journal of Experimental Psychology: Learning, Memory, and Cognition, 17, 3-19.

Tulving, E., \& Schacter, D. L. 1990 Priming and human memory systems. Science, 247, 301-306.

-2001.9.18 受稿, 2002.5.11 受理-

\section{付 録}

実験 I の刺激を巡る問題に関する実験を報告する。 方法，結果と考察は，次の通りである.

\section{方 法}

刺激材料, 装置, 線本数判断課題の手続きは, 実験 I と同じであった。デザインと被験者, 対称性判断課 題の手続きは，次の通りであった。

デザイン 対称性判断課題の刺激が異なったこと以 外は，実験 I と同じであった。この実験の対称性判断 課題では, 線本数判断課題におけるステレオグラムの ハーフイメージが両眼刺激として提示された。

被験者 正常な視力（矯正視力を含む）を有する東 海女子大学の学部学生 5 人が参加した.

対称性判断課題の手続き 注視点と刺激, マスク刺 激が両眼に提示された点が実験 I と異なった。それ以 外は，同じであった。

\section{結果と考察}

対称性判断課題の結果を Table A・1 に示す. Table $\mathrm{A} \cdot 1$ では, 学習条件の “対称図形と判断した試行数” の平均值と “非対称図形と判断した試行数” の平均 值, 未学習条件の “対称図形と判断した試行数” の平 均值と “非対称図形と判断した試行数” の平均值が対 称図形, 非刘称図形毎に示されている. 対称図形の正 
Table $A \cdot 1$

Results of symmetry judgement task

\begin{tabular}{llll}
\hline Stimulus type & Condition & \multicolumn{2}{c}{ Response } \\
& & "Symmetrical" "Asymmetrical" \\
\hline \multirow{2}{*}{ Symmetrical } & Studied & $8.8^{\mathrm{a})}(0.74)^{\mathrm{b})}$ & $1.2(0.74)$ \\
& Non-studied & $7.0(0.63)$ & $3.0(0.63)$ \\
& & & \\
Asymmetrical & Studied & $2.0(1.26)$ & $8.0(1.26)$ \\
& Non-studied & $0.8(0.40)$ & $9.2(0.40)$
\end{tabular}

a) Mean response of 5 paricipants. Minimum is 0 , and maximum is 10 .

b) Standard deviation.

答した試行数の平均值は，学習条件が未学習条件より 大きかった。対称図形の誤答した試行数の平均值は, 学習条件が末学習条件より小さかった。非対称図形の 正答した試行数の平均值は，学習条件が未学習条件よ り小さかった。非対称図形の誤答した試行数の平均值 は，学習条件が未学習条件より大きかった。

Table A・1の結果を西野 (2000) の議論に従って 分析した結果を Table A•2 に示す. 'Table A•2 には, 西野 (2000) の議論に従って求めた真の正答数が示さ れている。学習条件の真の正答数は, 未学習条件より 小さかった。また， $t$ 検定の結果は，学習条件と末学 習条件の真の正答数に有意差がないことを示した $(t(8)=1.13, n s)$. これらの結果は, 対称性判断のプ ライミング効果が生じなかったことを示している.
Table $\mathrm{A} \cdot 2$

True hits in the results of symmetry judgement task

\begin{tabular}{cl}
\hline Condition & \multicolumn{1}{c}{ True hits } \\
\hline Studied & $13.6^{\mathrm{a})}(1.50)^{\mathrm{b})}$ \\
Non-studied & $12.4(1.50)$
\end{tabular}

a) Mean number of true hits for 5 participants.

Minimum is 0 , and maximum is 20 .

b) Standard deviation.

線本数判断課題におけるステレオグラムのハーフイ メージを対称性判断課題の刺激としても, それを両眼 刺激として提示すると，構造記述システムに基づくプ ライミング効果が生じなかった。これは, 左眼・右眼 の刺激の一方が線本数判断課題と同一となっても，も う一方が異なることに起因すると考えられる。なお， 異なると言っても, その差異は, 両眼網膜非対応の量 に相当し，わずかである。したがって，構造記述シス テムは，符号化時と検索時の間の刺激の差異に影響さ れやすいと言えるであろう。

ところで, Cooper et al. (1992) によれば，構造記 述システムは，符号化時と検索時の間で刺激の左右が 反転しても，その影響を受けない。これは，構造記述 システムが符号化時と検索時の間の刺激の差異に影響 されにくいことを示す知見として注目され，この付録 の実験によって新たに得られた知見と合致しないと言 えよう。この矛盾を解くことは, 構造記述システムの 特性を解明する上で重要であり, 今後の課題となる。 